\title{
Effect of water temperature on mortality of Pacific oysters Crassostrea gigas associated with microvariant ostreid herpesvirus 1 (OsHV-1 $\mu$ Var)
}

\author{
Maximilian de Kantzow, Paul Hick*, Joy A. Becker, Richard J. Whittington
}

Faculty of Veterinary Science, The University of Sydney, 425 Werombi Road, Camden, NSW 2570, Australia

\begin{abstract}
The ostreid herpesvirus 1 microvariant (OsHV-1 $\mu$ Var) causes mass mortality of Pacific oysters Crassostrea gigas. Water temperature can directly influence the incidence of disease or correlate with seasonal changes in the environment and oyster physiology that modify the susceptibility of the oysters to disease. The effect of water temperature was evaluated in controlled laboratory conditions by intramuscular injection of OsHV-1 $\mu$ Var after acclimation of 8 mo old spat and 17 mo old adult oysters at 4 different temperatures $\left(14,18,22\right.$ and $\left.26^{\circ} \mathrm{C}\right)$. Mortality was 84 and $77 \%$ at 26 and $22^{\circ} \mathrm{C}$, respectively, compared to $23 \%$ at $18^{\circ} \mathrm{C}$ and nil at $14^{\circ} \mathrm{C}$. There was a statistically significant interaction between the dose of OsHV-1 $\mu$ Var and water temperature. At $18^{\circ} \mathrm{C}$, mortality occurred exclusively at a dose of $10^{6}$ OsHV-1 $\mu$ Var genome copies per oyster whereas at the higher temperatures, oysters challenged with $10^{3}$ copies per oyster also died. Mortality did not occur at $14^{\circ} \mathrm{C}$ and OsHV-1 $\mu$ Var was detected in tissues of only $1 \%$ of the oysters after $14 \mathrm{~d}$. When accounting for temperature and dose, spat $(8 \mathrm{mo})$ were 2.7 times more likely to die than adults $(17 \mathrm{mo})$. Our study confirms a direct effect of water temperature on infection and disease caused by OsHV-1 $\mu$ Var. We identified a threshold water temperature of between 14 and $18^{\circ} \mathrm{C}$ below which productive infection does not occur and the requirement for a higher dose of OsHV-1 $\mu$ Var to initiate infection at $18^{\circ} \mathrm{C}$ than at $22^{\circ} \mathrm{C}$. These results have implications for predicting and managing disease outbreaks caused by OsHV-1 $\mu$ Var.
\end{abstract}

KEY WORDS: Ostreid herpesvirus 1 - OsHV-1 $\mu$ Var · Pacific oyster • Crassostrea gigas · Water temperature $\cdot$ Laboratory challenge $\cdot$ Dose-response $\cdot$ Disease susceptibility

\section{INTRODUCTION}

A microvariant genotype of the species Ostreid herpesvirus 1 (OsHV-1) was first identified in 2008 in France (Segarra et al. 2010). This pathogen was shown to be associated with recurrent mass mortality events in the Pacific oyster Crassostrea gigas, with up to $100 \%$ mortality of juvenile oysters (Schikorski et al. 2011b, EFSA 2015). OsHV-1 is a member of the family Malacoherpesviridae within the order Herpesvirales (Davison et al. 2005, ICTV 2013). The World Organisation for Animal Health (OIE) defines micro-

\footnotetext{
${ }^{*}$ Corresponding author: paul.hick@sydney.edu.au
}

variant genotypes of OsHV-1 (OsHV-1 $\mu$ Var) as those which are characterised by a deletion in the microsatellite locus upstream of open reading frame (ORF) 4 , and several polymorphisms compared with the reference genotype (GenBank accession number AY509253) in ORF 4 (C region) and ORF 42/43 encoding an inhibitor of apoptosis. This definition incorporates several variations on the genotype first described as an OsHV-1 microvariant by Segarra et al. (2010).

Disease caused by OsHV-1 $\mu$ Var has since been identified in several countries including Australia

() The authors 2016. Open Access under Creative Commons by Attribution Licence. Use, distribution and reproduction are unrestricted. Authors and original publication must be credited. Publisher: Inter-Research · www.int-res.com 
(Jenkins et al. 2013), New Zealand (Bingham et al. 2013), Ireland (Peeler et al. 2012, Clegg et al. 2014), The Netherlands (Gittenberger et al. 2016), Italy (Domeneghetti et al. 2014), and Spain (Aranguren et al. 2012, Roque et al. 2012), where it has caused serious disruption or complete cessation of Pacific oyster production (Paul-Pont et al. 2014, EFSA 2015). Additionally, OsHV-1 $\mu$ Var has been detected in locations where the disease is absent (Dundon et al. 2011, Shimahara et al. 2012, Jee et al. 2013). The incidence of disease is strongly seasonal with occurrence limited from spring to autumn in waterways where OsHV-1 $\mu$ Var is endemic (Oden et al. 2011, Peeler et al. 2012, Pernet et al. 2012, Paul-Pont et al. 2014, Renault et al. 2014).

Elevation of water temperature during the spring and summer was associated with mass mortality events in Australia, France and Ireland (Pernet et al. 2012, Clegg et al. 2014, Paul-Pont et al. 2014, Renault et al. 2014). A threshold temperature above which mortality occurred has been reported to be $\sim 16^{\circ} \mathrm{C}$ in France and Ireland (Pernet et al. 2012, Clegg et al. 2014, Renault et al. 2014, Petton et al. 2015). Furthermore, in France a water temperature of $24^{\circ} \mathrm{C}$, above which mortalities cease to occur, has been suggested as upper threshold temperature (Pernet et al. 2012). In New South Wales, Australia, disease occurred when the mean water temperature was between 19 and $24^{\circ} \mathrm{C}$, although OsHV-1 $\mu$ Var DNA was present when the water temperature was lower (Paul-Pont et al. 2013a, 2014). In some cases, a sudden change in water temperature by several degrees Celsius rather than reaching a mean threshold temperature has preceded mortality associated with OsHV-1 $\mu$ Var (Clegg et al. 2014, Renault et al. 2014). However, disease has not always coincided with similar rapid changes in water temperature, suggesting that short- and long-term temperature changes and the presence of the virus are not the only triggers of mortality (Paul-Pont et al. 2013b, Clegg et al. 2014). The temperature of oysters present in the intertidal zone should not be assumed to be equal to the water temperature. As oysters may not be submerged at all times, temperature will also be influenced by the air temperature and solar radiation (Helmuth 1999).

Similar to expression of disease, Petton et al. (2013) found that transmission of the virus most efficiently occurred in the range of $16-22^{\circ} \mathrm{C}$ and did not occur at $13^{\circ} \mathrm{C}$. Other studies showed that an OsVH-1 infected tissue preparation remained infectious for $54 \mathrm{~h}$ at $16^{\circ} \mathrm{C}$ compared to $33 \mathrm{~h}$ at $25^{\circ} \mathrm{C}$ (Martenot et al. 2015) and that OsHV-1 in seawater retained infectivity for
$2 \mathrm{~d}$ at $20^{\circ} \mathrm{C}$ (Hick et al. 2016). Previously infected oysters showed high survival, and low quantities of OsHV-1 $\mu$ Var DNA were detected when held at $<14^{\circ} \mathrm{C}$, but high mortality and increased quantity of OsHV-1 $\mu$ Var DNA occurred when these oysters were subsequently exposed to $21^{\circ} \mathrm{C}$ (Pernet et al. 2015). This might indicate that a subclinical or latent infection with OsHV-1 $\mu$ Var occurs at low temperature (Pernet et al. 2015, Petton et al. 2015).

While a seasonal increase in water temperature above $16-18^{\circ} \mathrm{C}$ is associated with recurrent disease outbreaks caused by OsHV-1 $\mu$ Var, a range of concurrent seasonal changes in the host and environment may be more important in the pathobiology of the disease. Seasonal changes include the availability and type of food and the metabolic changes of the oyster (Soletchnik et al. 2006). The incidence of disease has varied with factors including: seasonal changes in reproductive effort and energy balance (Pernet et al. 2012, 2014); feeding (Evans et al. 2015); and management practices such as farming structures, immersion time and the density of oysters (Pernet et al. 2012, Paul-Pont et al. 2013a, Normand et al. 2014, Petton et al. 2015, Whittington et al. 2015a). Furthermore, the immune function of oysters is altered by water temperature (Green et al. 2014a,b).

Defining the effect of water temperature on disease caused by OsHV-1 $\mu$ Var is not possible from field observations alone. The aim of this study was to assess the direct effect of water temperature on the outcome of OsHV-1 $\mu$ Var infection under controlled laboratory conditions. Infection by intramuscular injection enabled administration of a measured dose of OsHV-1 $\mu$ Var DNA to all oysters at the same time and eliminated variation due to factors that influence virus transmission.

\section{MATERIALS AND METHODS}

\section{Oysters}

Two batches of triploid Pacific oysters Crassostrea gigas were produced in a Tasmanian hatchery and grown under commercial conditions on fixed long lines in the Shoalhaven River, New South Wales, Australia. Each batch was certified to be OsHV-1 $\mu$ Var free by a government laboratory, and this estuary is considered free of OsHV-1 $\mu$ Var (Herbert 2011). The 2 batches were transferred to the laboratory in January 2015 at the ages of 8 mo (spat, Batch ID: SPL14B, length $61.6 \pm 8.4 \mathrm{~mm}$ [mean $\pm \mathrm{SD}$ ], weight $8.5 \pm 3.7 \mathrm{~g}$ ) or 17 mo (adults, Batch ID: 
SPL13B, $48.9 \pm 6.4 \mathrm{~mm}, 11.6 \pm 4.6 \mathrm{~g})$. The batch of adult oysters had a greater mass but shorter shell length because of a deeper cup shape compared to younger oysters, reflecting previous growing conditions. Thus, rapidly growing young oysters and slower growing older oysters from commercial farming conditions were tested.

\section{Husbandry and acclimation}

The experiment was conducted in a temperaturecontrolled level 2 physical containment aquatic animal facility (University of Sydney, Camden Campus). The air temperature was maintained at $22^{\circ} \mathrm{C}$ with a $12 \mathrm{~h}$ photoperiod for the duration of the trial. The oysters were housed in $15 \mathrm{l}$ plastic tanks, 6 of which were connected in parallel in a 2501 recirculation system; there were 4 separate systems. Each system was attached to an independent bio-filter (Fluval 406) and a UV unit, both of which were removed for $2 \mathrm{~h} \mathrm{~d}^{-1}$ for feeding. The systems contained artificial seawater (ASW) with a salinity of 30 ppt prepared from dechlorinated water and artificial sea salt (Red Sea Salt). Water temperature was maintained for each system using thermostatically controlled aquarium heaters (AquaOne) and in-line chiller units (DBA-110, Daeil). Temperature data loggers (Thermocron) recording the temperature every 30 min were placed in the sump and in tanks 1 and 4 of each system. Salinity, total ammonia nitrogen and $\mathrm{pH}$ were measured every second day (API salt water master test kit, Aquarium Pharmaceuticals). Negative control oysters that were injected with an inoculum that was free of OsHV-1 $\mu$ Var were maintained separately in 51 of aerated ASW in vessels floated in each sump of each system so as to provide the same water temperature profile for acclimation and during the trial. Exposure to light, concentration of feed and stocking density were similar to that of the challenged oysters without the potential for waterborne exposure to OsHV$1 \mu$ Var. Water quality for the negative controls was maintained by exchanging $50 \%$ of the ASW each day.

Oysters were fed commercial algal mix Isochrysis, Pavlova, Thalassiosira weissflogii and Tetraselmis (Shellfish diet 1800, Reed Mariculture). A maintenance ration was calculated based on the oysters' wet meat weight according to the manufacturer's instructions and corresponded to $12.5 \mathrm{ml} \mathrm{d}^{-1}$ for each recirculation system and $1 \mathrm{ml} \mathrm{d}^{-1}$ for the controls (Reed Mariculture).
Oysters were purged without feed in ASW overnight and 10 adult (SPL13B) and 10 spat (SPL14B) oysters were randomly assigned to each of the 6 tanks in each recirculation system. A polypropylene mesh divider separated the age groups within each tank. Six oysters of each age were randomly assigned as negative controls at each temperature. The water temperature in each recirculation system was initially $20^{\circ} \mathrm{C}$ for $2 \mathrm{~d}$, reflecting water temperature in the field, before being adjusted by $1^{\circ} \mathrm{C} \mathrm{d}^{-1}$ until reaching the target temperatures: $14,18,22$ and $26^{\circ} \mathrm{C}$. Oysters were held at their target temperature for at least $48 \mathrm{~h}$ prior to inoculation.

\section{OsHV-1 $\mu$ Var inoculum}

A fresh stock of OsHV-1 $\mu$ Var was prepared immediately prior to the trial by amplification of an OsHV-1 $\mu$ Var stock in donor oysters (SPL13B, $\mathrm{n}=$ 8). The source of the stock virus was oysters from the Georges River (NSW, Australia) that were naturally infected with OsHV-1 $\mu$ Var in 2011. The the identity of the $\mu$ Var virus was confirmed by sequencing. A $0.2 \mu \mathrm{m}$ filtered tissue homogenate was prepared as described by Paul-Pont et al. (2015). The virus stock was archived at $-80^{\circ} \mathrm{C}$ with $10 \% \mathrm{v} / \mathrm{v}$ glycerol and $10 \% \mathrm{v} / \mathrm{v}$ foetal bovine serum (Sigma). The donor oysters were relaxed in $50 \mathrm{~g}$ $\mathrm{MgCl}_{2}$ (Sigma) per liter of dechlorinated tap water prior to injection of $100 \mu \mathrm{l}$ of a 1/100 dilution of the virus stock in sterile ASW into the adductor muscle. The donor oysters were maintained in ASW at $20^{\circ} \mathrm{C}$ for $4 \mathrm{~d}$ without feed.

The entire mantle and gill was excised from the donor oysters and homogenised by stomaching at maximum speed for 2 min (MiniMix, Crown Scientific) with $10 \mathrm{ml}$ ASW. The homogenate was made up to $1 / 10 \mathrm{w} / \mathrm{v}$ with additional sterile ASW and centrifuged at $1000 \times \mathrm{g}$ for $10 \mathrm{~min}$ at $4^{\circ} \mathrm{C}$. The supernatant was filtered to $0.2 \mu \mathrm{m}$ using syringe filters (Minisart, Sartorius). The OsHV-1 $\mu$ Var genome was quantified by $\mathrm{qPCR}$, and the clarified and filtered tissue homogenate was stored at $4{ }^{\circ} \mathrm{C}$ for $1 \mathrm{~d}$ prior to administration. Immediately prior to use the homogenate was diluted to 1 in 50 and 1 in $5000 \mathrm{v} / \mathrm{v}$ with $0.2 \mu \mathrm{m}$-filtered, sterile ASW to produce inocula with a dose of $10^{6}$ and $10^{3}$ OsHV$1 \mu$ Var genome equivalent copies per $100 \mu \mathrm{l}$. A negative control inoculum was prepared by the same procedure from a cryopreserved tissue homogenate prepared from oysters that tested negative for OsHV-1 $\mu$ Var DNA. 


\section{Inoculation of oysters with OsHV-1}

Oysters were relaxed in a $50 \mathrm{~g} \mathrm{MgCl}_{2}$ (Sigma) per liter of dechlorinated water maintained at the temperature of each treatment group. The oysters were challenged by injection of $10^{6}$ or $10^{3}$ OsHV-1 $\mu$ Var genome equivalent copies per oyster in a total volume of $100 \mu \mathrm{l}$ into the adductor muscle using a 25 gauge needle and $1 \mathrm{ml}$ syringe. Half of the tanks in each system were assigned the high dose of $10^{6}$ OsHV-1 $\mu$ Var genome copies and half the low dose of $10^{3}$ OsHV-1 $\mu$ Var genome copies. The same inoculum was administered to all oysters regardless of size. The negative control homogenate was diluted 1 in $50 \mathrm{w} / \mathrm{v}$ with $0.2 \mu \mathrm{m}$ filtered-sterile ASW prior to injection of $100 \mu \mathrm{l}$ into the adductor muscle of the control oysters.

\section{Experimental design}

For each of the 4 target water temperatures, 1 recirculation system consisting of 6 tanks was maintained. Each tank contained 10 oysters from the adult batch that were physically separated with a mesh divider from 10 oysters from the spat batch. There were 120 oysters at each temperature, half of which were challenged with the higher dose and the other with the lower dose of OsHV-1 $\mu$ Var. There were 12 negative control oysters for each water temperature, half from each age batch.

\section{Observation and sample collection}

Every oyster was inspected every $12 \mathrm{~h}$, and dead oysters were removed and stored at $-80^{\circ} \mathrm{C}$. Oysters were considered to be dead when they were open, non-responsive to disturbance of the tank and did not retract the mantle following stimulation with a 22 gauge needle. Feeding was monitored by visual observation of the rate at which algae were cleared from the water. A random sample of 20 live oysters was taken at $7 \mathrm{~d}$ post challenge to establish the prevalence of the virus in the 14 and $18^{\circ} \mathrm{C}$ treatment groups. All surviving oysters were sampled at the end of the trial, $14 \mathrm{~d}$ post challenge.

\section{Detection and quantification of OsHV-1 $\mu$ Var}

Tissues were processed according to previously described methods (Paul-Pont et al. 2013a, Whittington et al. 2015b). Briefly, a sample of gill and mantle was excised (pooled weight $0.08-0.12 \mathrm{~g}$ ) and placed in a $2 \mathrm{ml}$ screw cap tube with $1 \mathrm{ml}$ of ultrapure water (Ultrapur) and $0.4 \mathrm{~g}$ of $0.1 \mathrm{~mm}$ silica zirconia beads (Daintree Scientific). The samples were homogenised using a TissueLyser II (Qiagen) for $120 \mathrm{~s}$; the tubes were inverted for a second $120 \mathrm{~s}$ homogenisation cycle and then centrifuged at $900 \times g$ for $10 \mathrm{~min}$. The supernatant was stored at $-80^{\circ} \mathrm{C}$. Nucleic acids were purified from $50 \mu$ of supernatant with the MagMAX-96 Viral Isolation Kit (Ambicon, Life Technologies) and a magnetic particle processor (MagMAX Express 96 Applied Biosystems, Life Technologies) according to manufacturer's directions with the AM1836 deep-well standard program (Ambicon, Life Technologies). Purified nucleic acids were eluted in $75 \mu \mathrm{l}$ elution buffer and stored at $-20^{\circ} \mathrm{C}$.

A real-time quantitative PCR (qPCR) assay targeting ORF 99 of the OsHV-1 $\mu$ Var genome (B region) that encodes an inhibitor of apoptosis was modified from the method described by Martenot et al. (2010). Duplicate $25 \mu \mathrm{l}$ reactions were prepared with the Ag Path ID One-step RT-PCR kit (Life Technologies), BF and B4 primers $(900 \mathrm{~nm})$, OsHV-1B probe $(250 \mathrm{~nm})$ and $5 \mu \mathrm{l}$ of undiluted nucleic acid template from the sample of each individual oyster.

The thermocycling program conducted with a real time PCR system (Mx3000P, Stratagene) was $95^{\circ} \mathrm{C}$ for $10 \mathrm{~min}$ followed by 40 cycles of $95^{\circ} \mathrm{C}$ for $15 \mathrm{~s}$ and $60^{\circ} \mathrm{C}$ for $45 \mathrm{~s}$. Each plate of 96 reactions included a 10-fold dilution series of the plasmid pOSHV1-Breg for quantification (Paul-Pont et al. 2013b); duplicate OsHV-1 $\mu$ Var positive and negative tissue homogenates (extraction controls); and nil template controls. The ROX normalised FAM fluorescence signal was analysed with a propriety algorithm (Stratagene) to identify positive results and estimate the quantity of OsHV-1 $\mu$ Var DNA in samples in which both replicates had a logarithmic increase above the threshold value. Samples which satisfied the criteria for detection, but produced a threshold cycle $(\mathrm{Ct})$ value greater than the range of the standard curve, were indicated as below limit of quantification (BLOQ) and were not included in quantitative analyses.

\section{Statistical analysis}

Survival analyses were conducted according to the method described in Dohoo et al. (2003). The survival time was defined as the number of hours from OsHV$1 \mu$ Var exposure to mortality for oysters that tested positive for OsHV-1 $\mu$ Var DNA by qPCR. Kaplan- 
Table 1. Prevalence and quantity of OsHV-1 $\mu$ Var DNA (range of OsHV-1 $\mu$ Var genome equivalents mg m $^{-1}$ tissue) in apparently healthy Pacific oysters Crassostrea gigas at 7 and $14 \mathrm{~d}$ post challenge and total mortality after $14 \mathrm{~d}$, with viral concentration detected in oyster tissues at the time of death. Prevalence calculation: at $7 \mathrm{~d}$ post challenge, from samples randomly selected from all the apparently healthy oysters in each group; at $14 \mathrm{~d}$ post challenge, considering all surviving oysters. BLOQ: below the limit of quantification. For dead oysters, the number of oysters with greater than $10^{4} \mathrm{OsHV}^{-1} \mu \mathrm{Var}_{\text {genome }} \mathrm{copies}_{\mathrm{mg}}{ }^{-1}$ is given in parentheses; a threshold associated with mortality Oden et al. (2011). n/s: not sampled

\begin{tabular}{|c|c|c|c|c|c|c|c|c|c|}
\hline \multirow{3}{*}{$\begin{array}{l}\text { Water } \\
\text { tempe- } \\
\text { rature } \\
\left({ }^{\circ} \mathrm{C}\right)\end{array}$} & \multicolumn{6}{|c|}{ Apparently healthy oysters $\longrightarrow$} & \multicolumn{3}{|r|}{-Dead oysters } \\
\hline & & $-7 \mathrm{~d}$ post & t challenge & & $-14 \mathrm{~d}$ post & challenge - & & & \\
\hline & $\mathrm{n}$ & $\begin{array}{c}\text { Prevalence } \\
(\%)\end{array}$ & $\begin{array}{c}\text { esHV-1 } \mu \text { Var } \\
\text { quantity }\end{array}$ & $\mathrm{n}$ & $\begin{array}{c}\text { Prevalenc } \\
(\%)\end{array}$ & $\begin{array}{c}\text { e OsHV-1 } \mu \text { Var } \\
\text { quantity }\end{array}$ & $\mathrm{n}$ & $\begin{array}{c}\text { Mortality } \\
(\%)\end{array}$ & $\begin{array}{l}\text { OsHV-1 } \mu \text { Var } \\
\text { quantity }\end{array}$ \\
\hline 14 & 20 & 30.0 & BLOQ & 109 & 1.0 & BLOQ & 1 & 1.0 & 0 \\
\hline 18 & 20 & 65.0 & $\mathrm{BLOQ}-1.20 \times 10^{3}$ & 90 & 38.6 & $0-3.39 \times 10^{2}$ & 23 & 22.8 & $1.12 \times 10^{2}-7.08 \times 10^{4}(7)$ \\
\hline 22 & 0 & $\mathrm{n} / \mathrm{s}$ & - & 34 & 2.7 & $1.26 \times 10^{3}$ & 98 & 76.9 & $6.17 \times 10^{1}-6.76 \times 10^{5}(79)$ \\
\hline 26 & 0 & $\mathrm{n} / \mathrm{s}$ & - & 20 & 10.0 & BLOQ & 112 & 83.8 & $5.37 \times 10^{2}-1.58 \times 10^{7}(106)$ \\
\hline
\end{tabular}

Meier survival curves were plotted for each set of replicate treatment groups and for each experiment factor. Curves were compared using the Mantel-Cox log-rank test. The replicate treatment groups were not significantly different (all $\mathrm{p}>0.05$ ), so they were combined for further statistical analysis. Oysters that were alive at the end of the trial were considered to be censored at the time of sampling, regardless of OsHV1 DNA test status. A Cox proportional hazards (PH) model with shared frailty to account for clustering was fitted for treatment groups at 18,22 and $26^{\circ} \mathrm{C}$ using the Breslow method for tied events (STATA statistical software Version 13). A significant interaction between water temperature and dose was identified and these factors could not be separated. The assumptions of the PH model were assessed graphically using logcumulative hazard plots for each parameter in the model and statistically using the scaled Schoenfeld residuals. The goodness of fit was confirmed by the Nelson-Aalen cumulative hazard and Cox-Snell residue plots. The model was assessed under conditions of complete positive and negative correlation.

The quantities of OsHV-1 $\mu$ Var DNA were $\log _{10}$ transformed to satisfy the assumption of normality and compared across different treatments using a restricted maximum likelihood, linear mixed model (REML) (GenStat, 16th edition, 2015, VSN International). Water temperature, dose of virus and age of the oyster were considered as fixed effects, with tank as a random effect. Pairwise comparisons of estimated means used the least significant differences, with significance accepted at $\mathrm{p}<0.05$.

\section{RESULTS}

The water temperature remained within $1^{\circ} \mathrm{C}$ of the target temperature for each system after the acclima- tion period, with total ammonia nitrogen $<0.5 \mathrm{mg} \mathrm{l}^{-1}$ and $\mathrm{pH}$ 8.2. Mortality did not occur, nor was OsHV-1 $\mu$ Var DNA detected in the control oysters at any temperature $(\mathrm{n}=48)$. The control oysters were considered to be healthy based on their opening and closing responses throughout the trial.

There was no mortality associated with the OsHV$1 \mu$ Var challenge in oysters maintained at $14^{\circ} \mathrm{C}$ (Table 1), although 1 oyster died at $72 \mathrm{~h}$ post challenge and tested negative for OsHV-1 $\mu$ Var DNA. The total mortality at $18^{\circ} \mathrm{C}$ was $23 \%$ (Table 1 ), but none of the oysters injected with the lower dose of OsHV-1 $\mu$ Var died at this temperature. The mortality at 22 and $26^{\circ} \mathrm{C}$ was 77 and $84 \%$, respectively.

All oysters that died at 18,22 and $26^{\circ} \mathrm{C}$ tested positive for OsHV-1 $\mu$ Var DNA with between $6.17 \times 10^{1}$ and $1.58 \times 10^{7}$ OsHV-1 $\mu$ Var genome copies per $\mathrm{mg}$ of tissue. The quantity of OsHV-1 $\mu \mathrm{Var}$ DNA detected at the time of death was higher than in survivors and was not affected by the initial dose $(p=$ 0.51). The quantity of viral DNA at the time of death for oysters at $18^{\circ} \mathrm{C}$ was approx. 5- and 6 -fold lower than at 22 and $26^{\circ} \mathrm{C}$, respectively (Fig. 1a). Similarly, accounting for temperature, there was 2.5 times more OsHV-1 $\mu$ Var DNA detected in the spat batch of oysters compared to the adult batch (Fig. 1b).

There were a low prevalence and low quantities of OsHV-1 $\mu$ Var DNA in oysters surviving after $14 \mathrm{~d}$ (Table 1). A single surviving oyster at $14^{\circ} \mathrm{C}$, one at $22^{\circ} \mathrm{C}$ and 2 survivors at $26^{\circ} \mathrm{C}$ tested positive whereas $38.6 \%$ of 90 surviving oysters at $18^{\circ} \mathrm{C}$ were positive for OsHV-1 $\mu$ Var DNA (not shown). The dose strongly influenced the OsHV-1 $\mu$ Var status of survivors at $18^{\circ} \mathrm{C}_{i} 82 \%$ of those receiving the higher dose remained positive compared to $8.2 \%$ of those receiving the lower dose. The prevalence of OsHV-1 $\mu$ Var DNA $7 \mathrm{~d}$ after challenge in live oysters at $14^{\circ} \mathrm{C}$ was $30 \%$, and the quantity of virus was very low. At this 


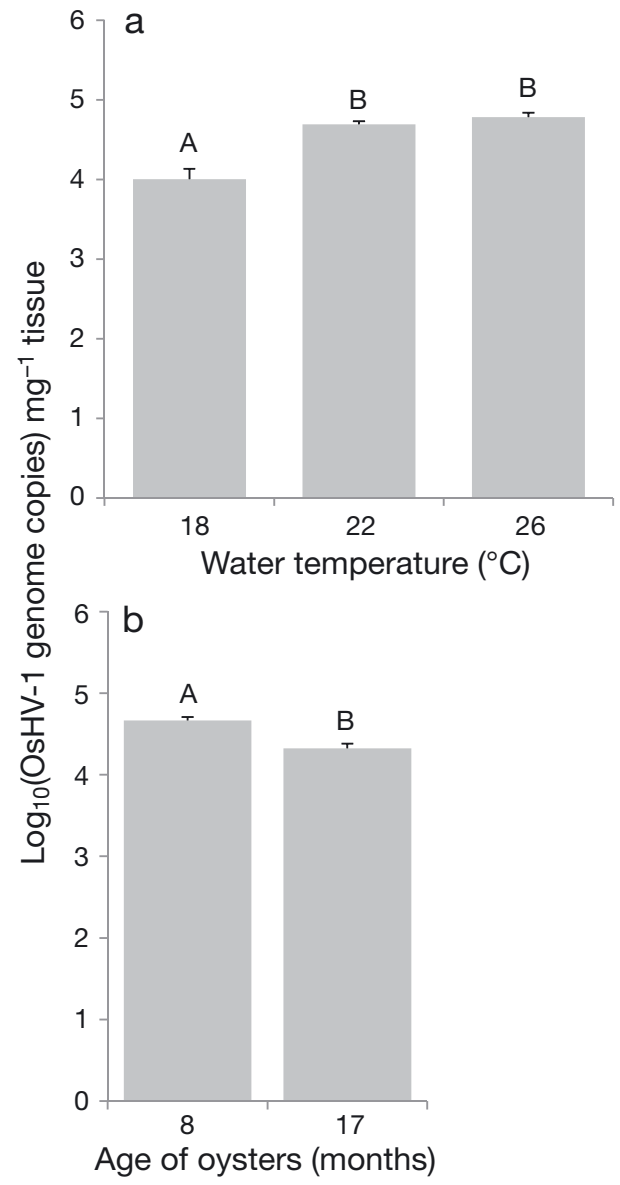

Fig. 1. Quantity (mean $+\mathrm{SE}$ ) of OsVH-1 $\mu$ Var DNA (logtransformed no. of OsHV-1 $\mu$ Var genome copies $\mathrm{mg}^{-1}$ tissue) in Pacific oysters Crassostrea gigas that died from OsHV-1 $\mu$ Var challenge at (a) different water temperatures, accounting for age, and (b) different ages, accounting for water temperature. The dose of OsHV-1 $\mu$ Var did not affect the quantity of viral DNA in the oysters that died $(p=0.51)$. Groups not sharing uppercase letters are significantly different $(p<0.05$, restricted maximum likelihood, linear mixed model)

time, OsHV-1 $\mu$ Var DNA was detected in $100 \%$ of live oysters at $18^{\circ} \mathrm{C}$ that were administered the higher dose, but in only $33 \%$ of the oysters challenged with the low dose $(n=10)$.

Mortality occurred in a single episode with no secondary peak as might have occurred if there was secondary infection caused by cohabitation with diseased oysters (Fig. 2). Initially, water temperature, age and dose of OsHV-1 $\mu$ Var were examined in isolation of the other factors, and there was no evidence of any violations of the assumptions of proportional hazards (Fig. 2). On any given day, all oysters held at $26^{\circ} \mathrm{C}$ were 1.9 times more likely to die with OsHV-1 $\mu$ Var infection compared to all oysters held at $22^{\circ} \mathrm{C}$ (i.e. the hazard ratio $[\mathrm{HR}] ; 95 \%$ confidence interval
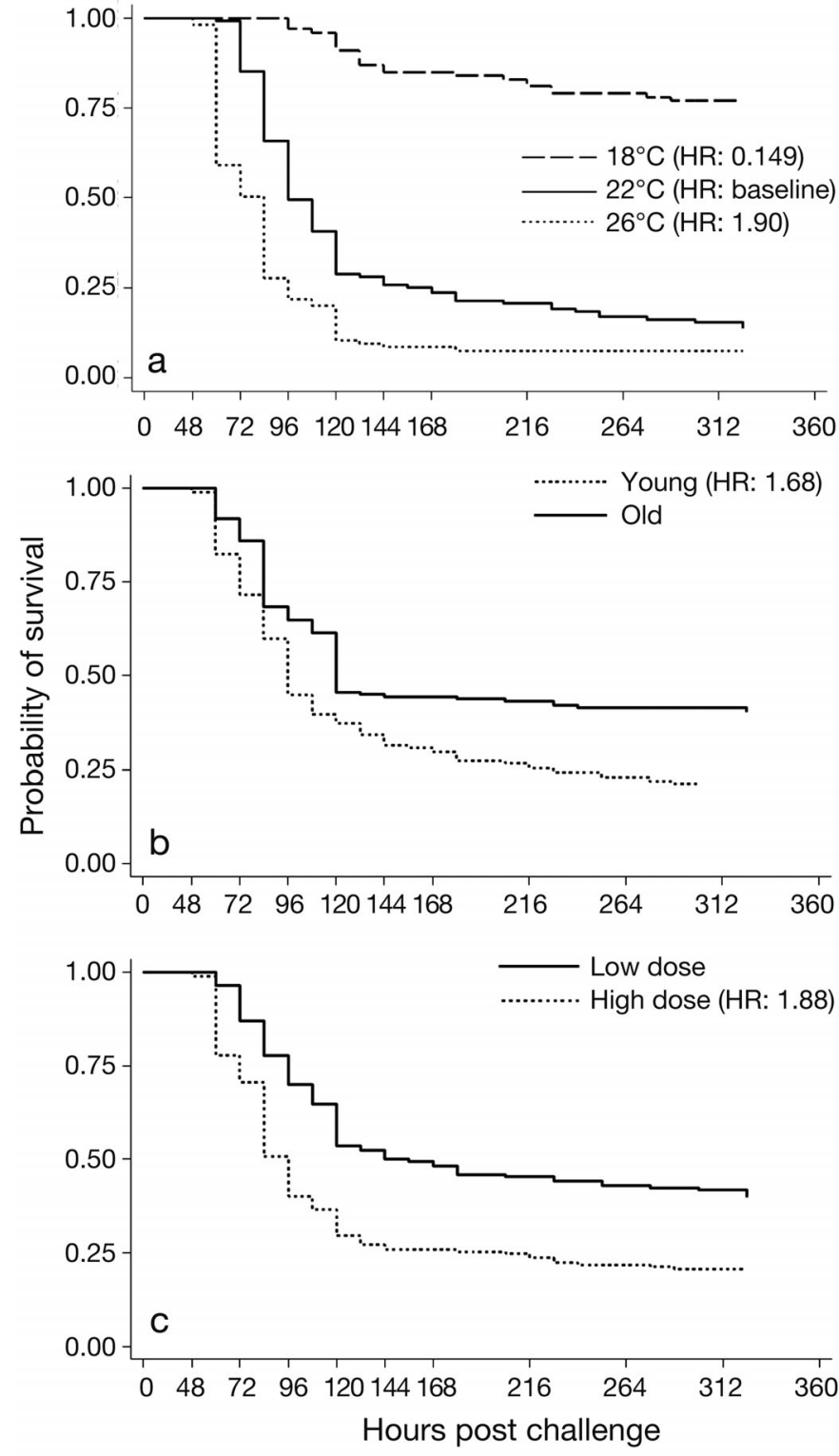

Fig. 2. Kaplan-Meier survival curves and hazard ratio (HR) for Pacific oysters Crassostrea gigas challenged with OsHV$1 \mu$ Var for each tested experimental factor: (a) water temperature (oysters at $14^{\circ} \mathrm{C}$ were negative for OsHV-1 $\mu$ Var and there was a single mortality), (b) age (8 mo old spat vs. 17 mo old adults), and (c) OsHV-1 $\mu$ Var dose level (low and high dose: $10^{3}$ and $10^{6}$ OsHV-1 $\mu$ Var genome copies $\mathrm{mg}^{-1}$ tissue, respectively)

[CI]: 1.45-2.50). The median survival time was 84 and $96 \mathrm{~h}$ for oysters held at 26 and $22^{\circ} \mathrm{C}$, respectively (Fig. 2A). There was a protective effect for oysters at $18^{\circ} \mathrm{C}$, with a hazard ratio $<1$ when compared to oysters held at $22^{\circ} \mathrm{C}$ (Fig. 2A). Over the experimental period, all oysters from the spat batch were 1.68 $(1.29-2.18,95 \%$ CI) times more likely to die with high quantities of OsHV-1 $\mu$ Var DNA compared to 


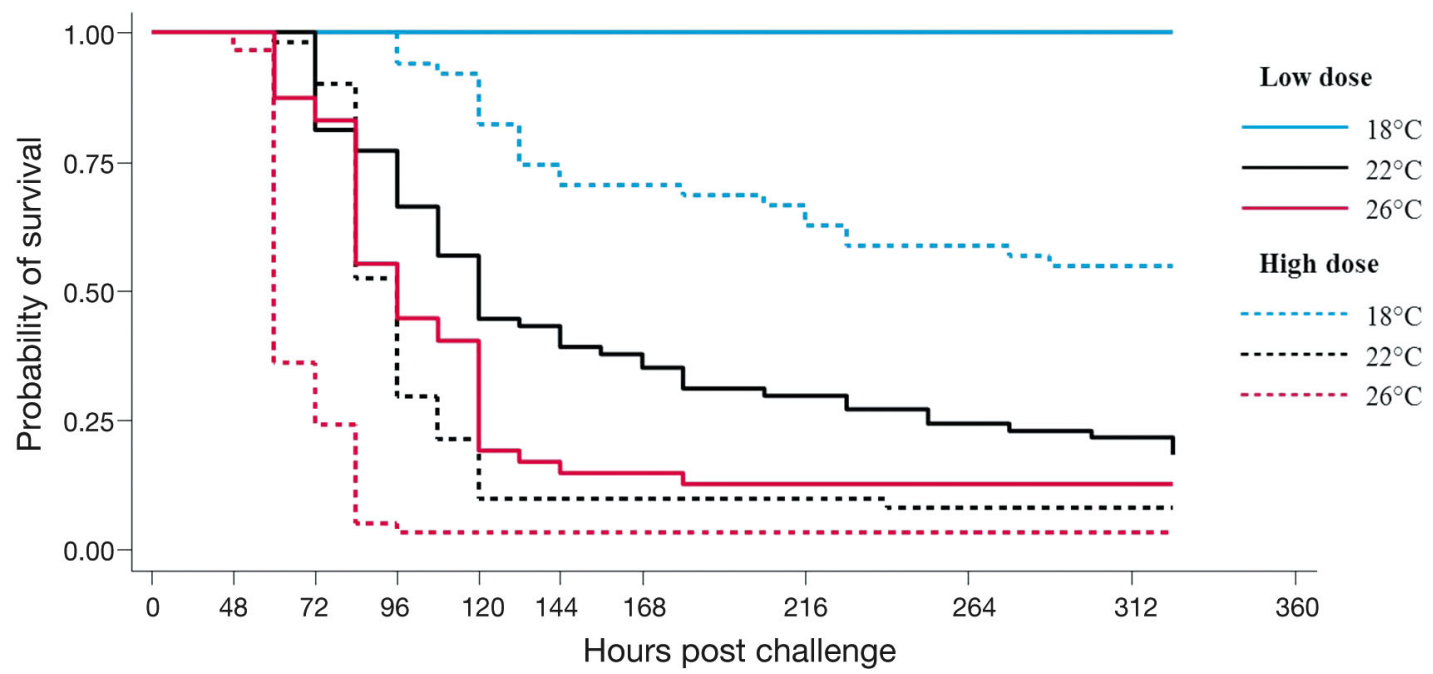

Fig. 3. Kaplan-Meier survival curves for Pacific oysters Crassostrea gigas challenged with OsHV-1 $\mu$ Var showing the interaction between water temperature $\left(18,22\right.$, and $\left.26^{\circ} \mathrm{C}\right)$ and dose $\left(10^{3}\right.$ and $10^{6}$ genome copies $\mathrm{mg}^{-1}$ tissue $)$

the older oysters (Fig. 2B). There was nearly twice the risk (HR 1.88; 1.45-2.44 95\% CI) of dying with OsHV-1 $\mu$ Var infection in all oysters given the high dose of OsHV-1 $\mu$ Var compared to the low dose exposure (Fig. 2C). The median survival time for all oysters given the high dose of OsHV-1 $\mu$ Var was $96 \mathrm{~h}$ compared to $144 \mathrm{~h}$ for the low dose.

The Cox PH model enabled a multivariable analysis. There was a significant interaction between water temperature and dose, indicating that the effect of water temperature was different depending on the challenge dose. The factors could not be separated and were considered as 6 separate treatment groups (Fig. 3). The oysters at $14^{\circ} \mathrm{C}$ were excluded from the PH model because mortality related to OsHV-1 $\mu$ Var infection did not occur. The final model included the treatment groups shown in Table 2 and was significant $(\mathrm{p}<0.001)$. On any given day, oysters held at $26^{\circ} \mathrm{C}$ were 2.1 and 3.6 times more likely to die with OsHV-1 $\mu$ Var infection compared to oysters at $22^{\circ} \mathrm{C}$ when challenged with low and high doses, respectively (Table 2). On any given day, oysters given a high dose of OsHV-1 were 2.1 and 3.8 times more likely to die with OsHV-1 $\mu$ Var infection compared to oysters challenged with the lower dose when held at 22 and $26^{\circ} \mathrm{C}$, respectively (Table 2). There was a protective effect for oysters at $18^{\circ} \mathrm{C}$ compared to the higher temperatures (Fig. 3, Table 2). The assumption of proportional hazards was not violated for age, as it did not interact with either water temperature or dose of OsHV-1 $\mu$ Var (all $\mathrm{p}>0.1$ ). Accounting for water temperature and dose, the young oysters were $2.7(2.1-3.695 \% \mathrm{CI})$ times more likely to succumb to OsHV-1 $\mu$ Var infection com-
Table 2. Hazard ratios for Pacific oysters Crassostrea gigas challenged with OsHV-1 $\mu$ Var for each tested experimental factor (temperatures $18,22,26^{\circ} \mathrm{C}$; doses $10^{3}$ [low] and $10^{6}$ [high] OsHV-1 $\mu$ Var copies per oyster; age [8 mo old spat]). There was a significant interaction between water temperature and dose of OsHV-1 $\mu$ Var. -: no mortality observed for the low dose at $18^{\circ} \mathrm{C}$

\begin{tabular}{|llcc|}
\hline \multirow{2}{*}{ Factor } & \multirow{2}{*}{ Level } & \multicolumn{2}{c|}{ Hazard ratio } \\
& & Point estimate & $95 \% \mathrm{CI}$ \\
\hline \multirow{2}{*}{ Low dose } & $18 \mathrm{vs.} 22^{\circ} \mathrm{C}$ & - & - \\
& 26 vs. $22^{\circ} \mathrm{C}$ & 2.1 & $1.5-2.9$ \\
High dose & 18 vs. $22^{\circ} \mathrm{C}$ & 0.2 & $0.1-0.2$ \\
& 26 vs. $22^{\circ} \mathrm{C}$ & 3.6 & $2.7-4.9$ \\
$22^{\circ} \mathrm{C}$ & High vs. low dose & 2.1 & $1.7-2.7$ \\
$26^{\circ} \mathrm{C}$ & High vs. low dose & 3.8 & $2.5-5.8$ \\
Age & Spat $(8 \mathrm{mo})$ & 2.7 & $2.1-3.6$ \\
\hline
\end{tabular}

pared to older oysters (Table 2). Residual analysis determined the PH model fit to the data and did not detect a significant effect when considered under conditions of complete positive and complete negative censoring.

\section{DISCUSSION}

This study demonstrates the important direct effect of water temperature on the expression of disease caused by OsHV-1 $\mu$ Var when administered by injection into the adductor muscle under controlled laboratory conditions. The intramuscular injection challenge method was first described by Schikorski et al. (2011b) in France and developed further in Australia by Paul-Pont et al. (2015). This allowed pathogenesis 
to be examined separately from factors that affect transmission and bypasses the external defences of the oyster. The quantity of OsHV-1 $\mu$ Var DNA in the inoculum administered to each oyster was measured, and the infection was not dependent on the transmission of variable quantities of virus present in the environment or shed by donor animals, as is the case with cohabitation models (Schikorski et al. 2011a, Petton et al. 2013, Evans et al. 2015). Unlike field studies, the laboratory environment enabled water temperature to be evaluated per se, with control of other factors that are also seasonally variable such as photoperiod and feed availability. The infection model did not introduce variability in factors other than controlled OsHV-1 $\mu$ Var exposure that might have influenced pathogenesis, such as co-infection with Vibrio spp. (Petton et al. 2013, 2015). Our experiment used 2 batches of oysters to demonstrate a marked and direct effect of water temperature on the outcome of challenge with OsHV-1 $\mu$ Var. The results are consistent with effects of water temperatures observed during disease in field conditions (Paul-Pont et al. 2014, Whittington et al. 2015a). Further work is required to replicate the experiment, test temperatures between 14 and $18^{\circ} \mathrm{C}$ in more detail and evaluate oysters with different genetic and life histories.

This study supports the observations of others who have shown a strong association between the onset of mortality and water temperature that is associated with warmer seasons (Petton et al. 2013, Clegg et al. 2014, Paul-Pont et al. 2014, Renault et al. 2014, Pernet et al. 2015). In the present study, mortality related to challenge with OsHV-1 $\mu$ Var did not occur in oysters at $14^{\circ} \mathrm{C}$. OsHV-1 $\mu$ Var infection may not have been able to establish at this temperature because the virus could not replicate or was cleared by an innate immune response. Alternatively, a subclinical infection may have been established that was not detected by qPCR (Pernet et al. 2015). The risk of disease in these oysters if water temperature subsequently increased was not determined. However, at $18^{\circ} \mathrm{C}, \mathrm{OsHV}-1 \mu \mathrm{Var}$ DNA persisted for at least $14 \mathrm{~d}$ in oysters that had been given the low dose, suggesting that viral replication may have occurred without inducing mortality. The incubation period for OsHV$1 \mu$ Var-associated mortality in naïve oysters exposed to infected oysters from the field at $17.5^{\circ} \mathrm{C}$ was $6 \mathrm{~d}$ (Petton et al. 2013). A procedure for demonstrating latent infection that involves warming oysters to $21^{\circ} \mathrm{C}$ has been reported (Pernet et al. 2015, Petton et al. 2015).

In this trial, mortality associated with OsHV-1 $\mu$ Var replication, as indicated by increased quantities of viral DNA at the time of death, occurred at $18^{\circ} \mathrm{C}$ but not at $14^{\circ} \mathrm{C}$ in conditions that were otherwise equal. A strong, direct effect of water temperature on the host-pathogen interaction was indicated, with increased mortality at higher water temperatures. The quantity of viral DNA that was detected in oysters at the time of death was higher with each increase in temperature from 18 to $26^{\circ} \mathrm{C}$. The disease outcome might also indicate a deleterious increase in the immune response to the virus that is promoted by the higher temperature (Green et al. 2014a). The effect of both water temperature and the rate of temperature change on the immune responses of the oyster, and the transcriptional changes in the virus genome present opportunities for further research.

In the present study, the threshold dose of OsHV-1 $\mu$ Var for disease expression was temperature dependent, and for a given dose, total mortality was higher at higher water temperatures. A clear implication of these results is that the dose of virus is likely to be a very important risk factor for an outbreak of disease caused by OsHV-1 $\mu$ Var. There is an apparent difference between the threshold temperatures at which OsHV-1 $\mu$ Var-associated mortalities occur in France $\left(16^{\circ} \mathrm{C}\right)$ compared to Australia $\left(21^{\circ} \mathrm{C}\right)$ (Pernet et al. 2012, Jenkins et al. 2013, Paul-Pont et al. 2014, Renault et al. 2014). It is possible that this difference is due to virus strain differences or differences in oyster genetics between Europe and Australia. Australian and French OsHV-1 $\mu$ Var isolates are closely related on available genetic sequence; however, comparative analysis has focused on phylogenetic similarities and not virulence traits (Jenkins et al. 2013). Alternatively, the differences might reflect different methods for measuring and reporting water temperature. There can be considerable diel variation in water temperature in the shallow near-shore waters where oysters are grown (Kaplan et al. 2003, Lucas et al. 2006). Thus, an average water temperature obtained in a main channel might not be completely informative.

The risk for OsHV-1 $\mu$ Var epidemics developing in aquaculture will increase with temperatures greater than $18^{\circ} \mathrm{C}$ due to a lower lethal dose of OsHV-1 $\mu$ Var and a higher replication rate of the virus. Thus, both the water temperature and the amount of OsHV-1 $\mu$ Var present will influence the time of the first outbreak of the season. The dose effect also offers a possible explanation for the sometimes high variation in mortality of oysters of the same age in disease outbreaks in the field (Paul-Pont et al. 2013a, 2014, Clegg et al. 2014). While the disease risk will be influenced by many factors, including those that affect transmission, the importance of dose and tem- 
perature was highlighted by this laboratory investigation, which controlled for extrinsic factors that complicate field observations. Disease mitigation strategies have been proposed based on field observations of factors that influence disease (Petton et al. 2015, Whittington et al. 2015a). Improved disease management and prediction of epidemics can be achieved based on better knowledge of the direct influence of water temperature and initial quantity of OsHV-1 $\mu$ Var on pathogenesis and total mortality.

The environments where oysters are cultivated, including the hydrodynamics of the bay or estuary, are suspected to play a major role in the transmission of the virus through water connectivity (Pernet et al. 2012, Paul-Pont et al. 2013b). Hydrodynamics also influence the local water temperature in the areas where oysters are grown. Generally, these are relatively shallow, likely to be warmed by the sun and subjected to greater temperature fluctuation than the deeper areas that are well mixed by currents (Pernet et al. 2012). Oysters grown on long-lines or in trays in the intertidal zone experience time out of water at low tide and may therefore be relatively heated or cooled compared to the ambient water temperature during this time (Paul-Pont et al. 2013a). The observations of oysters immersed at a static temperature may not provide a complete indication of the disease outcomes expected in cultivated oysters subject to the fluctuations of an inter-tidal environment.

\section{CONCLUSION}

This study confirms that water temperature directly influences mortality caused by OsHV-1 $\mu$ Var infection of oysters, consistent with the pattern of recurrent seasonal disease outbreaks. Higher water temperatures, in the range of $18-26^{\circ} \mathrm{C}$ probably increase the risk of epidemics associated with OsHV-1 $\mu$ Var due to a lower lethal dose and a higher viral replication rate. Mortality of oysters injected with OsHV-1 $\mu$ Var in laboratory conditions depended on the temperature of the water when other factors were controlled. Mortality did not occur and there was no evidence of viral replication at $14^{\circ} \mathrm{C}$. Yet the same challenge resulted in mortality exceeding $75 \%$ with a high rate of viral replication at 22 and $26^{\circ} \mathrm{C}$. The influence of the dose of OsHV-1 was evident at the intermediate temperature of $18^{\circ} \mathrm{C}$, where the lower dose did not result in mortality and the higher dose resulted in less severe disease compared to that which occurred at higher temperatures.
Acknowledgements. This project was funded by the Fisheries Research and Development Corporation and The University of Sydney. Oysters were donated by Shellfish Culture, Tasmania and were grown by Leon and Angela Riepsamen, Goodnight Oysters, Greenwell Point. Thanks to Alison Tweedie, Olivia Evans, Navneet Dhand, Craig Kristo, Stuart Glover and Slavicka Patten for technical assistance.

\section{LITERATURE CITED}

Aranguren R, Costa MM, Novoa B, Figueras A (2012) Detec-

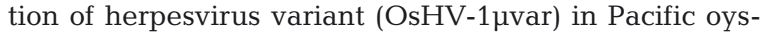
ters (Crassostrea gigas) in Spain and development of a rapid method for its differential diagnosis. Bull Eur Assoc Fish Pathol 32:24-29

Bingham P, Brangenberg N, Williams R, van Andel M (2013) Marine and freshwater investigation into the first diagnosis of ostreid herpesvirus type 1 in Pacific oysters. Surveillance (Wellingt) 40:20-24

Clegg TA, Morrissey T, Geoghegan F, Martin SW, Lyons K, Ashe S, More SJ (2014) Risk factors associated with increased mortality of farmed Pacific oysters in Ireland during 2011. Prev Vet Med 113:257-267

> Davison AJ, Trus BL, Cheng NQ, Steven AC and others (2005) A novel class of herpesvirus with bivalve hosts. J Gen Virol 86:41-53

Dohoo IR, Martin W, Stryhn H (2003) Veterinary epidemiologic research, 2nd edn. VER Inc, Charlottetown

> Domeneghetti S, Varotto L, Civettini M, Rosani U and others (2014) Mortality occurrence and pathogen detection in Crassostrea gigas and Mytilus galloprovincialis closegrowing in shallow waters (Goro lagoon, Italy). Fish Shellfish Immunol 41:37-44

> Dundon WG, Arzul I, Omnes E, Robert M and others (2011) Detection of type 1 Ostreid herpes variant (OsHV-1 $\mu$ var) with no associated mortality in French-origin Pacific cupped oyster Crassostrea gigas farmed in Italy. Aquaculture 314:49-52

EFSA (European Food Safety Authority) (2015) Oyster mortality. EFSA J 13:4122-4159

Evans O, Hick P, Dhand N, Whittington RJ (2015) Transmission of Ostreid herpesvirus-1 in Crassostrea gigas by cohabitation: effects of food and number of infected donor oysters. Aquacult Environ Interact 7:281-295

Gittenberger A, Voorbergen-Laarman MA, Engelsma MY (2016) Ostreid herpesvirus OsHV-1 $\mu$ Var in Pacific oysters Crassostrea gigas (Thunberg 1793) of the Wadden Sea, a UNESCO world heritage site. J Fish Dis 39: 105-109

Green TJ, Montagnani C, Benkendorff K, Robinson N, Speck P (2014a) Ontogeny and water temperature influences the antiviral response of the Pacific oyster, Crassostrea gigas. Fish Shellfish Immunol 36:151-157

> Green TJ, Robinson N, Chataway T, Benkendorff K, O'Connor W, Speck P (2014b) Evidence that the major hemolymph protein of the Pacific oyster, Crassostrea gigas, has antiviral activity against herpesviruses. Antiviral Res 110:168-174

> Helmuth B (1999) Thermal biology of rocky intertidal mussels: quantifying body temperatures using climatological data. Ecology 80:15-34

Herbert B (2011) Aquatic animal health. Anim Health Surveill Q Rep 16:8-9

> Hick P, Evans O, Looi R, English C, Whittington RJ (2016) 
Stability of Ostreid herpesvirus-1 (OsHV-1) and assessment of disinfection of seawater and oyster tissues using a bioassay. Aquaculture 450:412-421

ICTV (International Committee on Taxonomy of Viruses) (2013) Virus taxonomy 2013 release. http://ictvonline. org/virusTaxonomy.asp

Jee BY, Lee SJ, Cho MY, Lee SJ and others (2013) Detection of Ostreid Herpesvirus 1 from adult Pacific oysters Crassostrea gigas cultured in Korea. Fish Aquat Sci 16: 131-135

Jenkins C, Hick P, Gabor M, Spiers Z and others (2013) Identification and characterisation of an ostreid herpesvirus-1 microvariant (OsHV-1 $\mu$-var) in Crassostrea gigas (Pacific oysters) in Australia. Dis Aquat Org 105:109-126

Kaplan DM, Largier JL, Navarrete S, Guiñez R, Castilla JC (2003) Large diurnal temperature fluctuations in the nearshore water column. Estuar Coast Shelf Sci 57:385-398

> Lucas LV, Sereno DM, Burau JR, Schraga TS and others (2006) Intradaily variability of water quality in a shallow tidal lagoon: mechanisms and implications. Estuar Coasts 29:711-730

Martenot C, Oden E, Travaille E, Malas JP, Houssin M (2010) Comparison of two real-time PCR methods for detection of ostreid herpesvirus 1 in the Pacific oyster Crassostrea gigas. J Virol Methods 170:86-89

- Martenot C, Denechere L, Hubert P, Metayer L and others (2015) Virulence of Ostreid herpesvirus $1 \mu$ Var in sea water at $16{ }^{\circ} \mathrm{C}$ and $25^{\circ} \mathrm{C}$. Aquaculture 439:1-6

Normand J, Blin JL, Jouaux A (2014) Rearing practices identified as risk factors for ostreid herpesvirus 1 (OsHV-1) infection in Pacific oyster Crassostrea gigas spat. Dis Aquat Org 110:201-211

> Oden E, Martenot C, Berthaux M, Travaille E, Malas JP, Houssin M (2011) Quantification of ostreid herpesvirus 1 (OsHV-1) in Crassostrea gigas by real-time PCR: determination of a viral load threshold to prevent summer mortalities. Aquaculture 317:27-31

$>$ Paul-Pont I, Dhand NK, Whittington RJ (2013a) Influence of husbandry practices on OsHV-1 associated mortality of Pacific oysters Crassostrea gigas. Aquaculture 412413:202-214

Paul-Pont I, Dhand NK, Whittington RJ (2013b) Spatial distribution of mortality in Pacific oysters Crassostrea gigas: reflection on mechanisms of OsHV-1 transmission. Dis Aquat Org 105:127-138

Paul-Pont I, Evans O, Dhand NK, Rubio A, Coad P, Whittington RJ (2014) Descriptive epidemiology of mass mortality due to Ostreid herpesvirus-1 (OsHV-1) in commercially farmed Pacific oysters (Crassostrea gigas) in the Hawkesbury River estuary. Aquacult 422-423:146-159

- Paul-Pont I, Evans O, Dhand NK, Whittington RJ (2015) Experimental infections of Pacific oyster Crassostrea gigas using the Australian ostreid herpesvirus-1 (OsHV1) $\mu$ Var strain. Dis Aquat Org 113:137-147

$>$ Peeler EJ, Reese AR, Cheslett DL, Geoghegan F, Power A, Thrush MA (2012) Investigation of mortality in Pacific oysters associated with Ostreid herpesvirus-1 $\mu$ Var in the Republic of Ireland in 2009. Prev Vet Med 105:136-143

Pernet F, Barret J, Le Gall P, Corporeau C and others (2012) Mass mortalities of Pacific oysters Crassostrea gigas reflect infectious diseases and vary with farming prac- tices in the Mediterranean Thau lagoon, France. Aquacult Environ Interact 2:215-237

> Pernet F, Lagarde F, Le Gall P, D'Orbcastel ER (2014) Associations between farming practices and disease mortality of Pacific oyster Crassostrea gigas in a Mediterranean lagoon. Aquacult Environ Interact 5:99-106

Pernet F, Tamayo D, Petton B (2015) Influence of low temperatures on the survival of the Pacific oyster (Crassostrea gigas) infected with ostreid herpes virus type 1. Aquaculture 445:57-62

Petton B, Pernet F, Robert R, Boudry P (2013) Temperature influence on pathogen transmission and subsequent mortalities in juvenile Pacific oysters Crassostrea gigas. Aquacult Environ Interact 3:257-273

$>$ Petton B, Boudry P, Alunno-Bruscia M, Pernet F (2015) Factors influencing disease-induced mortality of Pacific oysters Crassostrea gigas. Aquacult Environ Interact 6: 205-222

Renault $\mathrm{T}$, Bouquet AL, Maurice JT, Lupo C, Blachier P (2014) Ostreid herpesvirus 1 infection among Pacific oyster (Crassostrea gigas) spat: relevance of water temperature to virus replication and circulation prior to the onset of mortality. Appl Environ Microbiol 80: $5419-5426$

$>$ Roque A, Carrasco N, Andree KB, Lacuesta B and others (2012) First report of OsHV-1 microvar in Pacific oyster (Crassostrea gigas) cultured in Spain. Aquaculture 324325:303-306

Schikorski D, Faury N, Pepin JF, Saulnier D, Tourbiez D, Renault T (2011a) Experimental ostreid herpesvirus 1 infection of the Pacific oyster Crassostrea gigas: kinetics of virus DNA detection by q-PCR in seawater and in oyster samples. Virus Res 155:28-34

Schikorski D, Renault T, Saulnier D, Faury N, Moreau P, Pepin JF (2011b) Experimental infection of Pacific oyster Crassostrea gigas spat by ostreid herpesvirus 1: demonstration of oyster spat susceptibility. Vet Res 42:27

- Segarra A, Pepin JF, Arzul I, Morga B, Faury N, Renault T (2010) Detection and description of a particular Ostreid herpesvirus 1 genotype associated with massive mortality outbreaks of Pacific oysters, Crassostrea gigas, in France in 2008. Virus Res 153:92-99

> Shimahara Y, Kurita J, Kiryu I, Nishioka T and others (2012) Surveillance of type 1 Ostreid herpesvirus (OsHV-1) variants in Japan. Fish Pathol 47:129-136

Soletchnik P, Faury N, Goulletquer P (2006) Seasonal changes in carbohydrate metabolism and its relationship with summer mortality of Pacific oyster Crassostrea gigas (Thunberg) in Marennes-Oléron bay (France). Aquaculture 252:328-338

Whittington RJ, Dhand NK, Evans O, Paul-Pont I (2015a) Further observations on the influence of husbandry practices on OsHV-1 $\mu$ Var mortality in Pacific oysters Crassostrea gigas: age, cultivation structures and growing height. Aquaculture 438:82-97

- Whittington RJ, Hick P, Evans O, Rubio A, Alford B, Dhand N, Paul-Pont I (2015b) Protection of Pacific oyster (Crassostrea gigas) spat from mortality due to ostreid herpesvirus 1 (OsHV-1 $\mu$ Var) using simple treatments of incoming seawater in land-based upwellers. Aquaculture 437:10-20

Submitted: April 11, 2016; Accepted: June 3, 2016

Proofs received from author(s): July 20, 2016 